\title{
Cutting Tool Life when Tapping Nickel Based Super Alloy
}

Milan Daňa, Miroslav Zetek, Václav Schorník

Regional Technological Institute, University of West Bohemia - Faculty of Mechanical Engineeering, Univerzitní 8, Pilsen 306 14, Czech Republic. E-mail: danam@rti.zcu.cz, zetek@rti.zcu.cz, schornik@rti.zcu.cz

This work deals with the issue of tapping Inconel 718 alloy. This material is known for its unique properties of high strength at high temperatures, corrosion resistance, high hardness, work hardening and low thermal conductivity. The machinability of Inconel 718 is very hard and cutting tool wear is high.This paper deals with creating internal threads by using monoliths taps. The taps are made of powder metallurgy high speed steel.The taps were provided with coating. Preparation of the hole for the thread has a huge impact on the cutting tool life. If the preparation is poor the inner face of the hole will be work hardened. This makes the cutting tool life far shorter. For the test, taps with different threads per chamfer were used. The second part of the paper is focused on the experiment where cutting tool life was monitored.

Keywords: Thread; Cutting tool life; Tool wear; Inconel 718

\section{Acknowledgement}

The present contribution has been prepared under project LO1502 'Development of the Regional Technological Institute' under the auspices of the National Sustainability Programme I of the Ministry of Education of the Czech Republic aimed to support research, experimental development and innovation.

\section{References}

[1] Special Metals Corporation, High-Performance Alloys for Resistance to Aqueous Corrosion, [cit. 2015-07-09] The available from: http:/www.parrinst.com/wp-content/uploads/downloads/2011/07/Parr_Inconel-IncoloyMonel-Nickel-Corrosion-Info.pdf

[2] KOŽMÍN, P. KŘÍŽ A. ROUD P. (2011). Drilling holes with increased accuracy. MM Industrial Spectrum 2011. number. 5 Available from: http://www.mmspektrum.com/clanek/vrtani-der-se-zvysenou-presnosti.html

[3] SLABÝ, O. (2009). Technology of rotary Inconel element manufacturing in Frencken Brno. In Brno, 2009. available from: https://www.vutbr.cz/www_base/zav_prace_soubor_verejne.php?file_id=17059. Brno University of technology

[4] ŠTOKMAN, M. (2014). Cutting force analysis when tapping. 77 pages. Brno University of technology, Faculty of Mechanical Engineering.In Brno, 2014. Available from: https://www.vutbr.cz/www_base/zav_prace_soubor_verejne.php?file_id=84147.

[5] PLATIT, Comparison of Machinability of Different Workpiece Materials, [cit. 2015-02-23]. The available from: http://www.platit.com/coating-features

[6] WALTER. (2009). Walter titex \& walter prototyp -The perfect thread. 2009. [cit. 2015-05-07]. The availible from: https://www.walter-tools.com/SiteCollectionDocuments/downloads/global/manuals/en-gb/handbook-drillingthreading-2009-en.pdf

[7] EMUGE FRANKEN, Thread cutting technology - clamping technology. [cit. 2015-03-09]. The availible from: http://www.goo-

gle.cz/url $2 \mathrm{sa}=\mathrm{t} \& \mathrm{rct}=\mathrm{j} \& \mathrm{q}=\&$ esrc $=\mathrm{s} \&$ source $=$ web $\& \mathrm{~cd}=1 \& \mathrm{ved}=0 \mathrm{CCAQFjAA} \& u r \mathrm{l}=\mathrm{http} \% 3 \mathrm{~A} \% 2 \mathrm{~F} \% 2 \mathrm{Fwww} . \mathrm{emug}$ e-franken3.com $\% 2$ Fdownload $\% 2$ Fcontent $\% 2$ FPrint $\% 2$ FPro-

spekte\%2FZS10038_CZGB_RevA.pdf\&ei=Lh5LVem-

NsLSU5mkgfgP\&usg=AFQjCNFGJC3c1ujt7XLLXWDzjsVHSJ_HSw

[8] WESSELY, E; HRUBINA, K; BALCZAK, S; HREHOVA, S \& MACUROVA, A. (2010). Optimum path design applied to cutting holes in parts. Annals of DAAAM for 2010 \& Proceedings of the 21 st International DAAAM Symposium, Volume 21, No. 1, ISSN 1726-9679 ISBN 978 3-901509-73-5, Editor B. Katalinic, Published by DAAAM International, Vienna, Austria, EU, 2010

[9] ZETEK, M., ČESÁKOVÁ, I., ŠVARC, V. (2013). Increasing cutting tool life when machining Inconel 718. In Collection of Working Papers for 24th DAAAM International Symposium. Vienna: DAAAM International, 2013. s. 1-6. ISBN: 978-3-901509-97-1, ISSN: 1877-7058 
[10] PISKA, M. SLIWKOVA P. (2015). Surface Parameters, Tribological Tests and Cutting Performance of Coated HSS Taps. In Procedia Engineering. Vienna: DAAAM International, 2015. Pages. 125-134. ISBN 978-3-90150999-5 ISSN: 1877-7058

[11] M. RAHMAN, W.K.H. SEAH, T.T. TEO. (1997). The machinability of Inconel 718. In.Journal of Materials Processing Technology, Volume 63, Issues 1-3, 1997, Pages 199-204, ISSN: 0924-0136.

[12] SCHORNÍK, V., ZETEK, M., DAŇA, M. (2015). The influence of working environment and cutting conditions on milling nickel based super alloys with carbide tools. In Procedia Engineering. Vídeň: DAAAM International Vienna, 2015. s.1262-1269. ISBN: 978-3-901509-99-5 , ISSN: 1877-7058

[13] STEININGER, A., SILLER, A., BLEICHER, F. Investigations Regarding Process Stability Aspects in Thread Tapping Al-Si Alloys. In Procedia Engineering. Vídeň: DAAAM International Vienna, 2014. s.1124-1132. ISBN: 978-3-901509-99-5 , ISSN: 1877-7058

[14] PETRU, J. SCHIFFNER, J. ZLAMAL, T. SADILEK, M. STANCEKOVA, D. (2015). Investigations of Cutting Tool Wear While MachiningInconel 718. In MANUFACTURING TECHNOLOGY. 2015. Vol. 15, No. 3 s. $396-$ 403. ISSN 1213-2489

[15] MADL, J. MARTINOVSKY, M. (2015). Cutting Tool Wear Monitoring. In MANUFACTURING TECHNOLOGY. June 2015, Vol. 15, No. 3 S. 380 - 384. ISSN 1213-2489

[16] NOVAK, M. NAPRSTKOVA, N. (2015). Grinding of the Alloy INCONEL 718 and Final Roughness of the Surface and Material Share. In MANUFACTURING TECHNOLOGY. December 2015, Vol. 15, No. 6. s.1015 - 1023. ISSN 1213-2489 